\title{
The Beneficiaries of Black Economic Empowerment in Polokwane Area of Limpopo Province, South Africa
}

\author{
Olabanji A Oni \\ University of Limpopo, School of Economics and Management \\ Department of Business Management, Private Bag X1106 Sovenga 0727, South Africa \\ Email: Olabanji.Oni@ul.ac.za \\ Olawale O Fatoki \\ University of Limpopo, School of Economics and Management \\ Department of Business Management, Private Bag X1106 Sovenga 0727, South Africa \\ Email: Olawale.fatoki@ul.ac.za
}

\section{Doi:10.5901/mjss.2014.v5n20p232}

\begin{abstract}
The aim of this paper is to investigate the beneficiaries of Black Economic Empowerment (BEE) policy in Polokwane area of Limpopo Province, South Africa. Data was collected through the use of self-administered questionnaires in a survey. The questionnaires were distributed to a convenient sample of micro business owners $(N=52)$ to respond on their perceptions and experiences regarding the beneficiaries of BEE in the Polokwane area of Limpopo Province, South Africa. Descriptive statistics was used for data analysis. The findings revealed that the highest beneficiaries of BEE according to race were the black people with $100 \%$, according to gender were the women with 59\% and according to income were the rich people with $96 \%$. Furthermore, the highest beneficiaries according to age group were the youth age group of 18-35years with $49 \%$ and according to education were those with secondary/ matric qualification with $35 \%$. The results suggest that BEE benefitted the blacks but the highest beneficiaries of the blacks were the more affluent people. It is recommended that the South African Government review the implementation of BEE to allow for a Broad Based Black Economic Empowerment that will close the gap between the rich and the poor. The government can make changes to the elements of the BEE scorecard to include education. Education is very important recipe for alleviating poverty, inequality and unemployment in South Africa and beyond.
\end{abstract}

Keywords: Beneficiaries; Black Economic Empowerment; Polokwane; South Africa.

\section{Introduction}

Black Economic Empowerment (BEE) was created to address the systematic exclusion of the majority of South Africans from full participation in the economy (South Africa BEE commission report 2001). The Department of Public Service and Administration (1998) stated in the White Paper Gazette Notice 564 of 1998 that Government inherited a public service which was strongly influenced by discriminatory employment policies and practices based on race, gender and disability.

Some of the challenges in South Africa are the legacy of apartheid, the growing inequality in income in the economy, the lack of appropriate skills amongst the wider South African population and the development of small medium and micro enterprises (SMMEs). Other challenges include poverty, unemployment, illiteracy rates, poor service delivery, huge backlogs in infrastructure development, lack of capital to finance SMMEs and inability of entrepreneurs and small business managers in managing change (Department of Health 2003).

To help address some of these challenges Government introduced the BEE policy in 1994 to support black owned businesses. In 1995, a national strategy for the development and promotion of small business in South Africa was tabled in Parliament. The creation of new black owned and black controlled enterprises was seen as a key component of the strategy. This led to the introduction of the National Small Business Act No.102 in 1996 to provide an enabling environment for SMMEs and to establish institutions to provide financial and other support to entrepreneurs. These institutions, Khula and Ntsika, have targeted substantial proportions of their programmes at black entrepreneurs by complying with the BEE policy (Department of Health 2003).The Department of Public Service and Administration (1998) stated that the white paper on affirmative action is a testimony of the Government's commitment to the transformation of the Public Service into an institution whose employment practices are underpinned by equity. To implement the BEE 
policy and ensure that the transformation indicated in the white paper is achieved, Government created the Department of Trade and Industry (DTI) to provide strategic direction in the development of policies and strategies that promote enterprise growth, empowerment and equity in the economy through the National Empowerment Fund (NEF), Small Enterprise Development Agency (SEDA) and National Small Business Advisory Council (Department of Trade and Industry 2011/12). Furthermore, the Department of Cooperative Governance and International Affairs (2009) stated that the Municipal Infrastructure Grant (MIG) programme was introduced in 2004 to alleviate poverty and accelerate service delivery in the Local Government. In 2009, the Department of Economic Development was created to co-ordinate South Africa Economic Policy and support small business activities using South Africa Micro Finance Apex Fund (SAMAF), Khula and Industrial Development Corporation (IDC) small business lending portfolio. Recently the three institutions were merged into the Small Enterprise Finance Agency (SEFA) in April 24, 2012.

It is important however, to stress that the government support for black owned SMMEs in compliance to the BEE policy is costly. For example, a study by the Department of Health (2003) indicated that a total of R2.2 billion was allocated to fund BEE initiatives for the 2002/2003 financial year. This fund came from the Department of Trade and Industry (DTI) and its various agencies, including Ntsika, Khula and the Industrial Development Corporation (IDC), as well as Land Bank, the Development Bank of Southern Africa (DBSA) and other Development Financial Institutions (DFl's). The findings of the study further indicated that Isibaya Fund contributed an amount of R321 million, the Umsombomvu Fund contributed R461 million and DBSA contributed R1.4 billion. Despite the introduction of the BEE policy to help address some of these challenges highlighted above, Mbeki (2004) argued that BEE created and benefited small powerful black elite. The above information indicates that the urgency of redress and the cost of empowering are high. $A$ study by Juggernath, Rampersad and Reddy (2011) however found that despite all these inputs, the outcomes of BEE are not known. This study therefore seeks to investigate the beneficiaries of BEE policy in Polokwane area of Limpopo Province, South Africa.

\section{The Objective of the Study}

The objective of the study is to identify the beneficiaries of BEE according to race, gender, income, age and education in Polokwane area of Limpopo Province, South Africa.

\section{Literature Review}

The Constitution of the Republic of South Africa Act No 108 of 1996 defines beneficiaries of BEE to include black South Africans who were born in South Africa, blacks born in exile who have black South African ancestors, blacks born in South Africa after apartheid who would have been discriminated against if apartheid was still in existence and black South Africans who were not born in South Africa but became citizens before the new constitution became law in 1993.According to the South Africa BEE Commission report (2001), BEE was defined as an integrated and coherent socio economic process located within the context of the country's national transformation programme, namely the RDP (Reconstruction and Development Programme). The report elaborated that BEE is aimed at redressing the imbalances of the past by seeking to substantially and equitably transfer and confer the ownership, management and control of South Africa's financial and economic resources to the majority of the citizens. It was also indicated in the report that BEE seeks to ensure broader and meaningful participation in the economy of black people to achieve sustainable development and prosperity. The commission defines three categories of Black empowerment: a Black company is at least $50.1 \%$ owned and managed by Black people, Black empowered firms are at least $25.1 \%$ owned and managed by Black people, and Black influenced firms are 5\% - 25\% Black owned and Managed (The New York Amsterdam News 2005). Department of Labour (2003) points out that section 9 of the Broad Based Black Economic Empowerment (BBBEE) Act focuses on the definition, qualification criteria, indicators to measure BEE, weighting and stakeholders guidelines in various sectors while section 10 focuses on the preferential procurement policy and criteria for entering partnership. The classification includes the generic broad based scorecard and narrow based scorecard.

The generic broad based scorecard presented in table 1 below applies to Exempted Micro Enterprises (EME). These are enterprises with an annual turnover of R5 million or less and all the seven pillars on the BEE score card must be included and added totalling 100 points. The specific scorecard presented in table 2 below applies to Qualifying Small Enterprises (QSE). These are enterprises with an annual turnover from R5 - 35 million and may choose any four of the pillars totalling 100 points. According to The Department of Trade and Industry (2008) verification is done to provide an assurance on the scorecard elements and the BBBEE status. The verification criteria for engagement are based on the eligibility of an exempted micro enterprise, the eligibility as a qualifying small enterprise, start-up enterprises, the element 
of BBBEE in terms of the generic scorecard, scorecards governing sector codes and the eligibility of specialised enterprises. Section 5.1.6 of the verification manual stated that beneficiaries that are listed as black trace beneficiaries and has sufficient and appropriate evidence with natural people who are beneficiaries qualify as black people in terms of code of good practice. Furthermore, section 5.1.7.1 of the verification manual of reporting on BBBEE in terms of codes of good practice emphasised that businesses are reviewed to ensure that the stated benefits will always be flowing to black people based on either a fixed percentage or according to a formula to prevent fronting.

Table 1: BEE generic broad based scorecard

\begin{tabular}{|l|c|c|}
\hline \multicolumn{1}{|c|}{ Element } & Weighting & Compliance Target \\
\hline Ownership & 20 points & $25 \%+1$ \\
\hline Management Control & 10 points & $(40 \%$ to $50 \%)$ \\
\hline Employment Equity & 15 points & $(43 \%$ to $80 \%)$ \\
\hline Skills Development & 15 points & $3 \%$ of payroll \\
\hline Preferential Procurement & 20 points & $70 \%$ \\
\hline Enterprise Development & 15 points & $3 \%(\mathrm{NPAT})$ \\
\hline Socio-Economic Development & 5 points & $1 \%(\mathrm{NPAT})$ \\
\hline
\end{tabular}

Source: South Africa BBBEE Act No 53 of 2003: Code of Good practice on BEE

Table 2: BEE specific narrow based scorecard

\begin{tabular}{|l|c|c|}
\hline Element & Weighting & Compliance Target \\
\hline Ownership & 25 points & $25 \%+1$ \\
\hline Management Control & 25 points & $50.1 \%$ \\
\hline Employment Equity & 25 points & $(40 \%$ to $70 \%)$ \\
\hline Skills Development & 25 points & $2 \%$ of payroll \\
\hline Preferential Procurement & 25 points & $50 \%$ \\
\hline Enterprise Development & 25 points & $2 \%(N P A T)$ \\
\hline Socio-Economic Development & 25 points & $1 \%(N P A T)$ \\
\hline
\end{tabular}

Source: South Africa BBBEE Act No 53 of 2003: Code of Good practice on BEE

\section{Research Methodology}

The survey was conducted in Polokwane, Limpopo Province of South Africa. The empirical approach consists of data collection through the use of self-administered questionnaire survey. The questionnaires were distributed to a convenient sample of micro business owners $(\mathrm{N}=52)$ to respond on their perceptions and experiences regarding the beneficiaries of BEE in the Polokwane area of South Africa. The convenience sampling and snowballing sampling methods were used because of the difficulty in obtaining the population of micro enterprises in the study area. Cooper and Schindler (2008) stated that convenience sampling is a non-probability sampling technique where subjects are selected because of their convenient accessibility and proximity to the researcher. Snowball sampling method is a non- probability sampling technique where existing study subjects recruit future subjects from among their acquaintances. The questionnaire was divided into two sections. The first part focused on the demographic information of the respondents. The second part of the questionnaire assessed the beneficiaries of BEE according to race, gender, income, age group and educational level. Descriptive statistics was used for data analysis.

\section{Findings and Discussions}

The table below shows the distribution of the demographic characteristics of the micro business owners in Polokwane area of Limpopo Province, South Africa. The sample consisted of 52 micro business owners. 
Table 3: Demographic information of respondents

\begin{tabular}{|l|l|c|c|}
\hline & & Frequency No & Percent \% \\
\hline Race & Black & 39 & 75 \\
\hline & Indian & 10 & 19 \\
\hline & Coloured & 3 & 0 \\
\hline & Chinese & 0 & 0 \\
\hline & White & 0 & 100 \\
\hline Gender & Total & 52 & 46 \\
\hline & Male & 24 & 54 \\
\hline & Female & 28 & 100 \\
\hline Age & Total & 52 & 38 \\
\hline & $18-35$ years & 20 & 35 \\
\hline & $36-50 y e a r s$ & 18 & 27 \\
\hline & $51-65$ years & 14 & 0 \\
\hline & Over 65years & 0 & 100 \\
\hline Education & Total & 52 & 0 \\
\hline & No formal & 0 & 0 \\
\hline & Primary & 0 & 77 \\
\hline & Secondary/Matric & 40 & 23 \\
\hline & Tertiary & 12 & 100 \\
\hline & & 52 & \\
\hline
\end{tabular}

Source: Author's Field work (2014).

The above table 3 indicates that $75 \%$ of the respondents were black, 19\% Indian, $6 \%$ Coloured, Chinese and White were not represented. The table also shows that $46 \%$ of the respondents were males and $54 \%$ were females. Furthermore, $38 \%$ of the respondents belong to the age group of $18-35$ years, $35 \%$ belong to the age group of $36-40$ years, $27 \%$ belong to the age group of 51-65 years and the age group of over 65 years was not represented. The table also points out that the majority of the respondents $77 \%$ were secondary/matric graduates and $23 \%$ were University graduates. The category of no formal education and primary education were not represented.

Table 4: The Beneficiaries of Black Economic Empowerment

\begin{tabular}{|l|c|c|}
\hline \multicolumn{1}{|c|}{ Variables \& Questions } & Frequency No & Percent $\%$ \\
\hline Race & & \\
\hline Total & 52 & 100 \\
\hline Do you think black people benefitted from BEE? & 52 & 100 \\
\hline \multicolumn{1}{|c|}{ Total } & 21 & 41 \\
\hline Income & 31 & 59 \\
\hline Do you think males benefitted from BEE? & 52 & 100 \\
\hline \multicolumn{1}{|c|}{ Age Group } & 50 & 96 \\
\hline \multicolumn{1}{|c|}{ Total } & 2 & 4 \\
\hline Do you think rich people benefitted from BEE? & 52 & 100 \\
\hline Do you think poor people benefitted from BEE? & & \\
\hline \multicolumn{1}{|c|}{ Total } & 25 & 49 \\
\hline \multicolumn{1}{|c|}{ Education } & 16 & 30 \\
\hline Do you think the age group of 18-35 years benefitted from BEE? & 11 & 21 \\
\hline Do you think the age group of 36-50 years benefitted from BEE? & 0 & 0 \\
\hline Do you think the age group of 51- 65 years benefitted from BEE? & 52 & 100 \\
\hline Do you think the age group of over 65 years benefitted from BEE? & & \\
\hline & 18 & 35 \\
\hline Do you think owners with secondary/ matric qualification benefitted from BEE? & 12 & 24 \\
\hline Do you think owners with diploma qualification benefitted from BEE? & 10 & 19 \\
\hline Do you think owners with first degree benefitted from BEE? & 7 & 13 \\
\hline Do you think owners with honours degree benefitted from BEE? & 5 & 9 \\
\hline Do you think owners with Master's degree benefitted from BEE? & 52 & 100 \\
\hline
\end{tabular}

Source: Authors Field work (2014). 
Table 4 shows the perceptions of the respondents on the beneficiaries of BEE. The table shows that $100 \%$ of the respondents reported that $\mathrm{BEE}$ benefited the black. According to gender, $41 \%$ of the respondents indicated that $\mathrm{BEE}$ benefitted the males and $59 \%$ indicated that BEE benefitted the females. Additionally, it is indicated from the table that $96 \%$ of the rich people and $4 \%$ of the poor people benefitted from BEE. Furthermore, the table also shows that $49 \%$ of the age group of 18-35 years benefitted from BEE, $30 \%$ of the age group of $36-50$ years benefitted and $21 \%$ of the age group of 51-65 years benefitted. There is no benefit for the age group of over 65 years (retired).Lastly, in terms of education micro business owners with matric qualification were the highest beneficiary of BEE with $35 \%$, followed by diploma with 24\%, first degree with 19\%, honours degree with $13 \%$ and finally Masters degree the lowest with 9\%.

\section{Conclusion}

The objective of the study was to identify the beneficiaries of BEE according to race, gender, income, age and education in Polokwane area of Limpopo Province, South Africa. The results suggest that BEE benefitted the blacks but the highest beneficiaries of the blacks were the rich people. Based on the results of this study, it is recommended that the South African Government review the implementation of BEE to allow for a Broad Based Black Economic Empowerment and inclusive growth. Government can make changes to the elements of the BEE scorecard to include education. Education is very important recipe for alleviating poverty, inequality and unemployment in South Africa and beyond.

\section{Limitation of the Study}

The study focused only on the owners of micro enterprises in Polokwane area of Limpopo Province, South Africa. Other research can extend the study to bigger businesses and bigger samples in other cities.

\section{References}

Cooper, D. R.. \& Schindler, P.S. (2008). Business Research Methods. (12 ${ }^{\text {th }}$ ed). New York: McGraw Hill Inc.

Department of Cooperative Governance and International Affairs (2009/10). Industry Guide: Infrastructure Service Delivery Level and Unit Cost. Pretoria: Government Printer.

Department of Health (2003).South Africa's Economic Transformation: A strategy for Broad Based Black economic Empowerment. KwaZulu-Natal: Department of Health.

Department of Labour (2003). Broad Based Black Economic Empowerment Act No.53 of 2003. Cape Town: Government Printer.

Department of Public Service and Administration (1998). White Paper Affirmative Action in the Public Service: General Notice 564 of 1998. Government Gazette, 394, 23 April 1998-No 18800.

Department of Trade and Industry 2011/12. A guide to the Department of Trade and Industry incentive schemes. Pretoria: Department of Trade and Industry.

Department of Trade and Industry (2008). Broad based Black Economic Empowerment Act No 53 of 2003: Framework for accreditation and verification by all verification agencies. Pretoria: Department of Trade and Industry.

Juggernath, S; Rampersad, R. \& Reddy, K. (2011). Corporate responsibility for socio economic transformation: A focus on broad based black economic empowerment and its implementation in South Africa. African Journal of Business Management, 5 (20): 82248234.

Mbeki, M. (2004). BEE has created "black elite". This Day Newspaper, 30 April: 23.

South Africa. (1996). Constitution of the Republic of South Africa Act 108 of 1996. Cape Town: Government Printer.

South Africa. (2001). The Black Economic Empowerment Commission Report. Johannesburg. Scottville Press. Chairman: Cyril Ramaphosa.

State pension fund doubles investments in SA. (2005). The New York Amsterdam News. 22-28 September: 2. 